\title{
Labor Migration and Social Development in Nepal
}

Gokarna Raj Aryal (PhD Scholar)*

\begin{abstract}
This paper attempts to highlight the existing situation of labor migration and its impacts on social progress, and to analyze how migration and social development are interrelated in Nepal. In recent years, the number of overseas migrants has significantly increased in Nepal because of diversified roles of the migrants as employees, students, businesspersons and tourists. One sad aspect to these roles of the Nepalese foreign labor migrants abroad is that they leave their homeland country because of lack of job opportunity, poverty, insecurity, and lack of proper infrastructures, low salary and income, lack of market for agriculture produce and high cost of agriculture production. The paper has been prepared with the help of secondary data. Around 59, 55,051 labor migrants legally migrated to 136 different countries of the world in 2019 from Nepal. In Nepal, remittance occupies almost one-fourth of the total GDP of our country. However, the inflow of abroad migration has slightly decreased from fiscal year 2019 because of COVID-19 pandemic in Nepal, though the remittance inflow into Nepal is practically stable. However, the contribution of the inflow of remittance to the overall national development has been often debated. The remittance sent to Nepal by foreign migrants have played an vital role not only for earning foreign exchange but also for education, health, sanitation, poverty alleviation, production of goods and services, and social development. Labour migration and social development of Nepal are not only interrelated, but the one also influences the other in a positive way.
\end{abstract}

Key words: Labor migration, inflow of remittance, GDP, causes \& social progress.

\section{Introduction}

Migration refers to the movement of people away from their place of usual residence, either within a state or across the international border. There are two types of migration. They are internal and international migration. Internal migration is an event in which people change their residence, but stay within the boundary of their country. There are

${ }^{*}$ Mr. Aryal is a Lecturer and Former Head at the Department of Population Studies, Patan Multiple Campus, TU, Lalitpur, Nepal.Email: goaryal243@gmail.com 
many reasons why people change their residence within the same country. Some of them are employment, better education and health services and improved life. It seems that internal migration is a common phenomenon in most of the developing countries.

An international migration refers to the cross border movement of people away from the country of their origin. Similarly, an international migration can be defined as a phenomenon in which people change their country of usual residence, and cross the international border. Temporary travel abroad for the purpose of recreation, holiday, business, medical treatment or religious pilgrimage does not entail a change in the country of usual residence (UNDESA, 1998).

Remittance is not a new phenomenon across the world. It is a byproduct of migration which has been perpetuated since human history started. A remittance is a transfer of money by a foreign migrant worker to an individual, their family or friends in their native country. It is an important part of international capital flow to the countries that export labor and skilled human resources. The inflow of remittance has become a global phenomenon in the recent years. Generally, there are two procedures for transferring of the remittance. They are domestic remittance and foreign or international remittance. Internal or domestic remittance occurs when people migrate for getting employment opportunity and send money to their families or relatives within the country. In other words, if the money gets remitted within the same country, then it is termed as internal or domestic remittance. Foreign or international remittance has been defined as inflow of money from foreign workers into their families or relatives in the native countries.

Development is a continuous process of social change, not merely a set of policies and programs instituted for some specific results. It is the effect of society's capacity to organize resources to meet challenges and opportunities. During the last five centuries, this process has picked up in speed and intensity and the last five decades has witnessed a marked surge in acceleration (ICPF, 1994). Sen (1995) views that social development is equality of social opportunities. According to Bilance (1997) social development is the promotion of a sustainable society that is worthy of human dignity by empowering marginalized groups, women and men, to undertake their own development, to improve their social and economic position and to acquire their rightful place in society. The Copenhagen Social Summit (1995) describes the social development in terms of three basic criteria: poverty eradication, employment generation and social harmony.

In general, social development is about improving the well-being of every individual in society. The success of society depends on the well-being of each citizen. In other words, 
social development is the investment in people. It requires the removal of barriers so that all citizens can journey toward their dreams with confidence and dignity. It is about helping people so they can move forward on their path to self-sufficiency. Social development is the process of improving the well-being of every individual in society. The indicators of social development are linked to the improvements in education, longevity, prosperity, equality and security.

\section{Statement of the Problem}

Every day around 1,600 Nepalese men and women leave the country in connection with foreign labor to different parts of the world (DoFE, 2018). Every year about 5, 00,000 Nepalese young people leave the country for overseas labor and they are currently working in more than 136 different countries around the world (MoLESS, 2020). Although the Government of Nepal has given high priority to overseas labor for a long time, it has not been able to explore new markets and ensure safer and better migration so far. Despite the fact that a large volume of remittance has been reported to have come into Nepal both legally and illegally, the major problem with this in the Nepalese societies is that most of the remittance has been found being spent on unproductive sectors and the consumptions of luxurious goods and services. International remittance depends mainly on the mobility and working efficiency of foreign labour workers. Due to domestic containment measures of the COVID-19 pandemic and the economic downturn, the demand for migrant labour is expected to fall in the world labour market. Migrant workers particularly of the developing countries are expected to experience a substantial fall in their wages and employment, causing severe distress to the livelihoods and economy of their countries of origin.

\section{Justification}

The research paper expects to contribute to the social improvements of the nation due to overseas migration and inflow of remittance. This study also focuses on how remittance is being utilized in our societies and how skills and new technologies of foreign migrants transforming in our societies and to evaluate the impacts on rural as well as urban communities. Furthermore, this research paper also suggests the causes and opportunities of overseas migration and inflow of remittance in Nepalese communities. This study also seeks how migration and social development are interlinked and factual situation of social progress by the movement of people.

Migration has major impacts on both the people and the places involved. When supported by appropriate policies, migration can contribute to inclusive and sustainable development 
in both origin and destination countries, while also benefitting migrants and their families. The crucial linkages between migration and development, including the opportunities and challenges that migration brings, are well established and accepted in a series of landmark agreements adopted by the United Nations Member States, including the Programme of Action of the International Conference on Population and Development held in 1994, the 2030 Agenda for Sustainable Development adopted in 2015, the New York Declaration for Refugees and Migrants from 2016, and most recently, the Global Compact for Safe, Orderly and Regular Migration, which was endorsed by the UN General Assembly in December 2018 (UN, 2019).

\section{Objectives}

The main objective of the study is to assess the situation of labor migration to foreign countries and its impacts on social progress in Nepal. The specific objectives of the study are to explore the recent trends of labor migration, to examine the trends of remittance received by the households, and to analyze how migration and social development are interrelated.

\section{Data and Methodology}

This study is entirely based on secondary data. The data are collected from different Economic Surveys; Nepal Living Standard Survey; Ministry of Finance; Department of Foreign Employment; Central Bureau of Statistics and Nepal Human Development Reports. Furthermore, Ministry of Labor, Employment and Social Security, Government of Nepal, and Nepal Rastra Bank published data are widely used. Likewise, existing literatures related to migration, remittance and social development are intensively used.

\section{Interpretation of the Data and Results}

\section{Inflow of Remittance}

Remittance is a transfer of money by a foreign migrant worker to an individual, their family or friend in their native country. It is an important part of international capital flow to the countries that export labor and skilled human resources. The inflow of remittance has become a global phenomenon in the recent years. Nepal is one of the major remittancereceiving members of the developing countries in the world. Remittance is a major source of foreign exchange earnings in many developing countries.

The percentage of households receiving remittance has increased from 23 percent in $1995 / 96$ to about 56 percent in 2010/11 of Nepal, and the share of remittance in household 
income has risen from about 27 percent to about 31 percent during the same period (NLSS, 2010/11). The total received amount of remittance has increased from NPRs. 47.22 billion in 2001/02 to NPRs. 875.0 billion in 2019/20 (MoF, 2020).

Table 1: Distribution of the inflow of remittance in Nepal, FY 2001/02-2019/20

\begin{tabular}{|c|c|c|}
\hline Fiscal Years & $\begin{array}{c}\text { Inflow of remittance } \\
\text { (In Rs. Billio.n) }\end{array}$ & $\begin{array}{c}\text { Remittance income } \\
\text { in \% of GDP }\end{array}$ \\
\hline $2001 / 02$ & 47.22 & \\
\hline $2005 / 06$ & 65.54 & 27.7 \\
\hline $2010 / 11$ & 253.6 & 29.0 \\
\hline $2013 / 14$ & 543.3 & 29.6 \\
\hline $2014 / 15$ & 617.3 & 26.9 \\
\hline $2015 / 16$ & 665.1 & 25.1 \\
\hline $2016 / 17$ & 699.0 & 25.4 \\
\hline $2017 / 18$ & 755.0 & 23.23 \\
\hline $2018 / 19$ & 879.3 & \\
\hline $2019 / 20$ & 875.0 & \\
\hline
\end{tabular}

Source: Ministry of Finance, Government of Nepal, 2020

Table 1 exhibits that Nepal received a total of NPRs. 47.22 billion remittance in the fiscal year 2001/02. This table also reveals that Nepal received NPRs. 65.54 billion remittance in 2005/06. Likewise, Nepal received NPR 253.6 billion remittance in 2010/11, NPRs. 543.3 billion in 2013/14, NPRs. 617.3 billion in 2014/15, NPRs. 665.1 billion in 2015/16, and NPRs. 699.0 billion remittance received in 2016/17, respectively. Nepal is one of the major remittance-receiving countries of the world. Nepal received a total of NPRs. 755 billion remittance from 136 different countries in 2017/18, which constituted 25.1 percent of the Gross Domestic Product (GDP) of the country. Similarly, Nepal received a total of NPRs. 879.3 billion remittance in fiscal year 2018/19, which is a contribution of 25.4 percent to the national GDP in Nepal. In the past 10 years, the inflow of remittance has been increasing gradually in Nepal. In the 2019/20 alone, Nepal received NPR 875.0 billion remittance, equivalent to GDP ratio of 23.23 percent. In Nepal, remittance occupies almost one-fourth of the total GDP of our country. However, the contribution of inflow of remittance to the overall national development have been often debated. 


\section{Migration by Sex and Provinces of the Contemporary Residence in Nepal}

Nepal has the provision of seven provinces as the Constitution of Nepal, 2072 B.S. These provinces have been created based on their population, geography, resources and economic efficiency. However, they may vary in their strength from one to another. The highest percentage of migrants as a percentage of the total population has found in Bagmati Pradesh $(47.3 \%)$ and the lowest percentage of migrants has found in Karnali Pradesh (26.1\%) in Nepal.

Table 2: Distribution of migrants by sex and provinces and their share to the total population, Nepal, 2017/18

\begin{tabular}{|l|c|c|c|c|c|c|}
\hline \multirow{2}{*}{ Provinces } & \multicolumn{4}{|c|}{ Migrants (in thousands) } & \multicolumn{2}{c|}{ Migrants in \% of the total population } \\
\cline { 2 - 7 } & Male & Female & Total & Male & Female & Total \\
\hline Province 1 & 576 & 1278 & 1854 & 25.2 & 49.5 & 38.1 \\
\hline Province 2 & 240 & 1433 & 1673 & 8.5 & 45.3 & 27.9 \\
\hline $\begin{array}{l}\text { Bagmati } \\
\text { Pradesh }\end{array}$ & 1232 & 1680 & 2912 & 40.3 & 54.3 & 47.3 \\
\hline $\begin{array}{l}\text { Gandaki } \\
\text { Pradesh }\end{array}$ & 279 & 717 & 1014 & 26.7 & 50.8 & 40.2 \\
\hline $\begin{array}{l}\text { Lumbini } \\
\text { Pradesh }\end{array}$ & 454 & 1168 & 1622 & 20.7 & 44.4 & 33.7 \\
\hline $\begin{array}{l}\text { Karnali } \\
\text { Pradesh }\end{array}$ & 125 & 359 & 484 & 15.1 & 35.0 & 26.1 \\
\hline $\begin{array}{l}\text { Sudur- } \\
\text { pashchim } \\
\text { Pradesh }\end{array}$ & 240 & 712 & 952 & 19.7 & 44.4 & 33.8 \\
\hline Nepal & $\mathbf{3 1 6 3}$ & $\mathbf{7 3 4 7}$ & $\mathbf{1 0 5 1 0}$ & $\mathbf{2 3 . 4}$ & $\mathbf{4 7 . 4}$ & $\mathbf{3 6 . 2}$ \\
\hline
\end{tabular}

Source: $C B S, 2019$.

Table 2 reveals that the distribution of migrants by sex and provinces and their share to the total population of Nepal. This table also exhibits that the highest percentage of migrants has been found in Bagmati Pradesh (2912 thousands) followed by province 1 (1854 thousands), province 2 (1673 thousands), Lumbini Pradesh (1622 thousands), Gandaki Pradesh (1014 thousands) and Sudurpashchim Province (952 thousands), respectively. The lesser percentage of the migrants has been obtained in Karnali Pradesh (484 thousands). However, it is to be noted that 10, 510 thousands people migrated from Nepal in fiscal year 2017/18. Among them 3, 163 thousands were males and 7, 347 
thousands were females in Nepal. The main reason for female migration is marriage.

\section{Reasons for Migration}

In Nepal, migration is increasing day by day. There are two types of migration, internal and external. Internal migration is due to marriage, study, quality of life, job opportunity, security issues. In recent years, the number of foreign labor migrants has meaningfully enlarged because of varied roles of the migrants as employees, students, businessmen, tourists, etc. Because of the lack of employment opportunities at home, men and women are forced to leave homeland.

Table 3: Distribution of reasons for migration from rural and urban residence in Nepal, $2017 / 18$

\begin{tabular}{|l|c|c|c|c|c|c|}
\hline \multirow{2}{*}{ Reasons for Migration } & \multicolumn{3}{|c|}{ Number (in thousands) } & \multicolumn{3}{c|}{ Percent } \\
\cline { 2 - 7 } & Urban & Rural & Total & Urban & Rural & Total \\
\cline { 2 - 7 } & Urban & Rural & Total & Urban & Rural & Total \\
\hline Marriage & 56 & 5615 & 5672 & 1.8 & 76.4 & 54.0 \\
\hline Other family reasons & 1033 & 899 & 1932 & 32.7 & 12.2 & 18.4 \\
\hline Start a new business & 231 & 34 & 265 & 7.3 & 0.5 & 2.5 \\
\hline Study/training & 501 & 321 & 822 & 15.8 & 4.4 & 7.8 \\
\hline Looking for work & 480 & 95 & 575 & 15.2 & 1.3 & 5.5 \\
\hline Easier lifestyle & 662 & 290 & 952 & 20.9 & 3.9 & 9.1 \\
\hline Other reasons & 199 & 94 & 292 & 6.3 & 1.3 & 2.8 \\
\hline \multicolumn{1}{|c}{ Nepal } & $\mathbf{3 1 6 3}$ & $\mathbf{7 3 4 5}$ & $\mathbf{1 0 5 1 0}$ & $\mathbf{1 0 0}$ & $\mathbf{1 0 0}$ & $\mathbf{1 0 0}$ \\
\hline
\end{tabular}

Source: $C B S, 2019$.

Table 3 shows the main reasons for migration from rural and urban residence in Nepal. This table also reveals that the major cause of migration is found to be marriage (54\%), followed by other family reasons $(18.4 \%)$, easier lifestyle $(9.1 \%)$, study and training (7.8\%), looking for work (5.5\%) and other reasons $(2.8 \%)$. Only smaller percentage the persons is migrating for starting a new business $(2.5 \%)$ in Nepal.

\section{Uses of Remittance}

Almost 31 percent of income among remittance receiving households in Nepal comes from remittance. Most of the received remittance goes to daily consumption and loan repayment. Almost 79 percent of the total remittances received by the households is 
taken up for daily consumption, while 7 percent is occupied by loan repayment. Other uses are to buy household property (5\%) and to receive education (4\%). Only a lesser percentage of the remittance $(2 \%)$ is used for capital formation and the remaining $(3 \%)$ is used for other purposes (NLSS, 2010/11). Analyzing the remittance trend of the past decade, remittance entering Nepal accounts for about one-fourth of the total GDP. In people's general perception in Nepal, 90 percent of the remittance received in this way is being spent on daily consumption. Furthermore, the rest of the remittance is spent on education, health, business, purchasing land and housing, and repayment of loans. Overall, remittance entering Nepal has consistently played a significant role in the social development of the country. Similarly, migrants from Nepal who have gone to different countries of the world for foreign employment have found that after achieving various skills abroad, they have returned and settled down in their homeland, and got involved in various businesses such as poultry farming, agriculture and industries.

\section{Conclusion}

Nepal is a multi-cultural, multi-racial, multi-religious and multi-lingual country. It is to be noted that the modern history of Nepal starts with the establishment of the Gorkha kingdom in the $18^{\text {th }}$ century. The history of foreign labor migration from Nepal has started after the Nepalese enrollment in British Army as "Gurkhas" since 1815 A.D. According to the report of DoFE 2018, every day around 1,600 Nepalese men and women leave the country in connection with foreign labor to different parts of the world. Every year about 5, 00,000 Nepalese young people leave the country for overseas labor, and they are currently working in more than 136 different countries around the world. Nepal is one of the major remittance-receiving countries of the world. According to the report of Ministry of Finance, Nepal received a total of NPR 879.3 billion remittance in 2018/19, which constituted 25.4 percent of the Gross Domestic Product (GDP) of the country. In the past 10 years, the inflow of remittance has been increasing gradually in Nepal. Due to domestic containment measures of the COVID-19 pandemic and the economic downturn, the demand for migrant labour is expected to fall in the world labour market. Migrant workers particularly of the developing countries are expected to experience a substantial fall in their wages and employment, causing severe distress to the livelihoods and the economy of their countries of origin. For a long time, remittances have played a significant for the enhancement of Nepal's economy. The remittance sent to Nepal by foreign labours have played an important role not only for earning foreign money but also for education, health, employment, poverty alleviation and social development. Labour migration and social development of Nepal are not only correlates, but also have causal relationship between them. 


\section{Acknowledgements}

Iwouldliketoexpressmysincere gratitudetotheUniversity GrantsCommissionforawarding me the $\mathrm{PhD}$ fellowship and research supportin 2077/078. I amalso grateful to the Department of Population Studies, Patan Multiple Campus, TU, Lalitpur for publishing this article.

\section{References}

Bilance, A. (1997). A world in balance-Bilance stands for social development: Policy paper. Oegstgeest, Netherland.

Central Bureau of Statistics (CBS). (2011). Nepal living standards survey, 2010/11. Statistical Report. Kathmandu, Nepal.

Central Bureau of Statistics (CBS). (2019). Report on Nepal labor force survey, 2017/18. Kathmandu, Nepal.

Department of Foreign Employment (DoFE). (2018). Labor migration for employment. A status report for Nepal, 2014/15. Kathmandu: Department of Foreign Employment, Ministry of Labor and Employment, Government of Nepal, Nepal.

International Commission on Peace and Food (ICPF). (1994). Uncommon opportunities: An agenda for peace and equitable development, Zed Books. United Kingdom.

Ministry of Finance (MoF). (2020). Economic survey, 2019/20. Kathmandu: Ministry of Finance, Government of Nepal, Singh Durbar, Nepal.

Ministry of Labor, Employment and Social Security (MoLESS). (2020). Nepal labor migration report, 2020. Kathmandu: Ministry of Labor, Employment and Social Security, Government of Nepal, Nepal.

Sen, A., \& Dreza, J. (1995). India economic development and social opportunity. Oxford University Press. Delhi, India.

United Nations (UN). (1995). The Copenhagen declaration and programme of action: World summit for social development. New York, USA.

United Nations (UN). (2019). International migration 2019, highlights. Department of Economic and Social Affairs Population Division, New York.

United Nations Department of Economic and Social Affairs (UNDESA). (1998). Recommendations on statistics of international migration. United Nations Publication.https://unstats.un.org/unsd/publication/SeriesM/SeriesM_58rev1E.pdf 